\title{
CASA, CORPO, PALAVRA: SUBVERSÃO ESPACIAL SOB PERSPECTIVA FILOSÓFICA, EM A OBSCENA SENHORA D, DE HILDA HILST
}

Ana Yanca da Costa Maciel

Resumo: Para demonstrar a subversão no espaço da casa, corpo e palavra, a partir das imagens poéticas tecidas pela personagem Hillé, em A obscena senhora $D$ ([1982] 2001), de Hilda Hilst (1930-2004), optou-se pela terminologia da Topoanálise de Gaston Bachelard, em $A$ poética do espaço ([1957] 1988), cuja perspectiva privilegia a vivência do espaço para além da objetificação. Para complementar o estudo da casa, usouse os estudos de Elódia Xavier (2012), por se tratar de uma narrativa de autoria feminina, demonstrando que a protagonista da trama reconfigura o espaço doméstico, pois não se detém às tarefas comumente atribuídas à mulher. Desta maneira, usa-se como apoio a filosofia feminista, tendo como referência Ivone Gebara (2017), para refletir sobre o modo como o corpo feminino foi privado da vida intelectual, por estar enclausurado no espaço doméstico. Nesse sentido, propõe-se que a trama não é esvaziada devido à ausência do cenário descritivo e geográfico em que habita a protagonista, mas todo corpo fala de algum lugar e está em algum lugar. Para isto, usa-se as contribuições de Michel Foucault (1986), em De outros espaços. Sendo assim, defende-se a perspectiva filosófica que compreende o reconhecimento da importância dos afetos ao lado da razão, leitura possível através das personagens no espaço.

Palavras-chave: Espaço. Topoanálise. Hillé. Hilda Hilst. Filosofia feminista.

Abstract: To demonstrate the subversion in the space of the house, body and word, based on the poetic images woven by the character Hille, in A obscene Senhora D ([1982] 2001) by Hilda Hilst, the terminology of Topoanalysis by Gaston Bachelard, in The poetics of space ([1957] 1988), whose perspective privileges the experience of space beyond objectification, was chosen as theoretical basis. To complement the study of the house, the studies of Elódia Xavier (2012) were used, as it is a narrative of female authorship, demonstrating that the protagonist of the plot reconfigures the domestic space, as she does not stop at the tasks commonly attributed to women. In this way, feminist philosophy 
is used as a support, having as reference Ivone Gebara (2017), to reflect on the way in which the female body was deprived of intellectual life, for being enclosed in the domestic space. In this sense, it is proposed that the plot is not emptied due to the absence of the descriptive and geographical scenario in which the protagonist lives, but every body speaks from somewhere and is somewhere. For this, the contributions of Michel Foucault (1986), in Of other spaces are used. Therefore, the philosophical perspective which includes the recognition of the importance of affections alongside reason, a possible reading through the characters in space, is defended.

Keywords: Space. Topoanalysis. Hillé; Hilda Hilst. Feminist philosophy.

\section{CONSIDERAÇÕES INICIAS}

A mulher dentro de cada um Não quer mais silêncio, psiu. A mulher de dentro de mim cansou de pretexto. A mulher de dentro de casa fugiu do seu texto.

Elza Soares

Este trabalho tem como foco de aprofundamento demonstrar a subversão no espaço doméstico, a partir das imagens poéticas tecidas pela personagem Hillé, em A obscena senhora D ([1982] 2001), de autoria da escritora brasileira Hilda Hilst (1930-2004).

Para pensar o espaço da casa, optou-se pela terminologia da Topoanálise designada por Gaston Bachelard, em $A$ poética do espaço, caracterizada, de modo geral, como "o estudo psicológico sistemático dos locais de nossa vida íntima" ([1957] 1988, p. 114). Ao formular a concepção topoanalítica, o filósofo parte da problemática provocada no contexto da "imaginação poética". 
A partir da observação de que a atualidade da imagem poética não pode ser reduzir às "causalidades psicológicas" (BACHELARD, 1988, p. 95), essa perspectiva filosófica da poesia destitui qualquer base que queira justificar 0 ato poético como um impulso impensado, ou um simples eco do passado da vida do(a) escritor(a).

Assinala-se que os aspectos biográficos e/ou sociais são significativos para compreender o legado literário de um artista, sobretudo quando se trata da ficção de autoria feminina, pois as lutas e lutos das mulheres que estiveram por muito tempo silenciadas têm sido o fio condutor de suas tramas, uma forma de romper a invisibilidade a que foram destinadas. Na reflexão de Claudio Carvalho:

É preciso simbolizar o real para não nos perdermos definitivamente nele, mas, ao simbolizá-lo, perdemos, por assim dizer, uma espécie de contato íntimo com esse mesmo real. Assim, muitas vezes, as pulsões reprimidas retomam sob a forma de linguagem. Permitir o retorno do reprimido, através do simbólico, é ainda uma das funções mais importantes do fazer artístico. (1999, p. 118)

Nesse sentido, tais aspectos devem ser relacionados à obra com prudência, pois, da mesma forma que não se faz literatura somente com concepções teóricas, também não 
se pode afirmar que ela é feita inteiramente com a simples transcrição das experiências da vida não ficcional. Há o trabalho de selecionar a palavra, pensar a estética para torná-la uma potência a fim de impactar quem vai ler/ouvir o texto e estabelecer uma conexão íntima de encantamento e criticidade.

Deste modo, a "prudência científica" (BACHELARD, 1988, p. 96) é citada no sentido de que a causalidade do eco é significativa, mas são as transformações proporcionadas pela ressonância dessa vivência, embutidas no modo de contar, que dão dinamismo e atualidade à imagem poética.

Pensar o espaço da poética da casa é um percurso que leva ao entendimento da alma humana e lhe é atribuído o "valor ontológico" (BACHELARD, 1988), porque, ao mesmo instante em que a casa abriga o corpo, o corpo é uma casa que cria para si uma liturgia do habitar, ritos ou experiências subjetivas que, na medida em que vão incorporando possibilidades, vão constituindo um cosmos. Assim, a trama está concentrada na relação entre a personagem e o interior da morada, de modo que a casa é visualizada enquanto espaço vivido.

Conjectura-se que a trama no vão da escada modifica o modo feminino de estar em um espaço com papéis definidos 
e construídos socialmente, a partir de uma imposição patriarcal sobre o corpo feminino. Essa imposição determina identidades fixas pelo gênero que gera; nas palavras de Heleieth Saffioti: "Formas de violência e silenciamento da vida das mulheres ao longo dos séculos da história. [...] Qualquer transgressão desses papéis "recebidos" era considerada como uma infração à sociedade, à natureza e a Deus" (2015, p. 11).

A divisão das funções domésticas ainda é um aporte para fortalecer o sexismo, uma vez que as mulheres são incumbidas, especificamente, de criar filhos, manter a higiene e organização do lar. Conforme Saffioti, a "dominaçãoexploração" (2015, p. 59) vai se naturalizando, porque se criou a ideia de que a mulher é o coração da casa, por ser sentimentalista, enquanto o homem é a razão. E, para afirmar sua masculinidade, não pode colaborar com as funções domésticas, estabelecendo relações de poder baseada na diferença sexual e controle conjugal.

Neste sentido, o próprio gênero acaba por se revelar uma camisa de força: o homem deve agredir, porque o macho deve dominar a qualquer custo; e a mulher deve suportar agressões de toda ordem, porque seu "destino" assim o determina. (SAFFIOTI, 2015, p. 90) 
Assim, a mulher é comumente inferiorizada e subordinada ao esforço dos trabalhos no espaço familiar, para que, na sua velhice, possa repassar não apenas os ensinamentos dessas atividades, como também, repassar o seu silenciamento às suas sucessoras. A história das sociedades do passado demonstra que a mulher não era convidada à construção intelectual sobre o mundo, tudo o que se sabia sobre o feminino foi retratado pela perspectiva masculina.

Nesse sentido, a divisão entre feminino e masculino consiste em identidades conceituadas levando em consideração a questão do provedor econômico versus reprodutora da vida. Assim, o percurso da humanidade marginalizou a intelectualidade feminina em detrimento do cuidado do lar. Por outro lado, não se pode esquecer de que o sistema capitalista também se apropriou da luta das mulheres, para dela extrair a força de trabalho em condições de subalternidade.

Sabe-se que, após a Revolução Industrial (1760 - 1840), a situação da mulher no espaço doméstico passa a ser vista como uma posição menos elevada, criando-se então a ideia de que o empoderamento feminino estaria em empregar sua força de trabalho nos espaços públicos, como, por exemplo, o setor industrial. Ocorre é que a mulher passa a exercer dupla jornada: 
trabalha em casa e fora dela. Quem não tem com quem deixar os filhos, e não pode trabalhar fora, é considerada limitada intelectualmente, pois não consegue pensar em assuntos filosóficos, políticos ou econômicos para além de sua realidade.

Essa perspectiva teve respaldo científico com a investigação capciosa realizada pelo antropólogo José Carlos Rodrigues, em o Tabu do corpo (2006), ao tomar como exemplo de "gramática gerativa do discurso comportamental" a visão sobre política das donas-de-casa de classe média urbana do Rio de Janeiro.

Perguntamos sobre os pontos fundamentais de atuações a que a ação política deveria visar. Responderam, de um modo geral, de ação deveria proporcionar "ruas e cidades limpas", "alimentação para todos", "assistência social ao menor", "melhores condições de saúde", "instrução melhor e mais acessível". Estas expressões correspondem aos seus discursos conscientes. Observamos, contudo, que estas expressões tinham muito a ver com suas posições de donas-de-casa e que poderiam ser aproximadas de expressões do tipo 'quartos e salas limpos e arrumados', 'mantimentos suficientes e alimentos bem preparados', 'educação e saúde das crianças', e assim por diante. $\mathrm{O}$ fato é que existe um modelo 'doméstico', subjacente ao discurso manifesto, que exprime a consciência que as donas-de-casa têm da vida política. Este modelo subjacente dita a forma pela qual o modelo explícito e consciente será expresso. 
Em outros termos, a vida doméstica fornece o modelo por meio do qual a vida política será concebida e conhecida. Este modelo, através do qual a consciência se forma, é basicamente, inconsciente. (2006, p. 43 - 44)

A apuração dos dados da pesquisa realizada foi com uma pequena população de uma parte da localidade geográfica, cujos resultados generalizam e são usados para embasar o posicionamento que subestima a intelectualidade das donasde-casa. Usando as próprias palavras do autor: "que grau de clareza delineia a consciência?" (RODRIGUES, 2006, p. 43).

Nesse sentido, Rodrigues não capta a dimensão demandada pela questão. Mas usou-se de um dado científico para afirmar que a criticidade e capacidade intelectual das mulheres que cuidam da casa é limitada ao espaço doméstico. Vale lembrar a memória de escritoras que antes de colaborarem intelectualmente com jornais, eram donasde-casa que liam e escreviam sobre os distintos assuntos políticos e filosóficos, a exemplo de Cora Coralina, Maria Carolina de Jesus e mesmo Hilda Hilst, que se formou em Direito, mas não atuou na profissão, dedicou-se inteiramente à criação literária e teve como principal fonte de produção artística o espaço da Casa do Sol.

É nesse sentido que se usa como apoio a filosofia feminista, tendo como referência Ivone Gebara (2017), 
porque é pertinente repensar essas construções sociais e, inclusive, baseadas cientificamente, que impediram as mulheres de participarem da vida intelectual, enclausuradas na dominação e violência do espaço doméstico.

Foram os homens quem teoricamente
definiram a nossa natureza, as nossas
funções, nossos corpos, os nossos atributos
e os nossos limites. A filosofia masculina
construiu seus cânones sobre o mundo e
os comportamentos sociais humanos sem a
participação direta das mulheres. (GEBARA,
2017, p. 13)

A filosofia feminista contribui no sentido de repensar o silenciamento, as tentativas de ocultamento e espaços ocupados por corpos subalternizados e dominados pelas estruturas socioculturais e poderes políticos. A condição biológica feminina não pode ser critério para que ela não participe da construção de ideias, independentemente de ela ser dona-de-casa. Essa também é uma crítica apontada pela professora Elódia Xavier (2012) em relação às análises bachelardianas sobre a representação da casa na literatura.

Não se pode desconsiderar que o estudo do filósofo trouxe significativas contribuições, mas teve como objeto de análise apenas as casas representadas nas poéticas de autores ingleses, e que esse estudo traz espacializações que remetem aos espaços felizes, isto é, a Topofilia. 
Enquanto a representação da casa na construção narrativa de mulheres tem demonstrado o espaço doméstico como um elemento estrutural de tensão e subversão. Para complementar a perspectiva bachelardiana, os estudos sobre obras produzidas por mulheres dos anos de 1897 a 2011 analisadas por Xavier (2012) são pertinentes, pois demonstram que o espaço da casa na dicção de autoria feminina é representado para além de um adorno que compõe a estrutura narrativa.

Nem sempre a casa será um espaço feliz, mas um espaço onírico de problematizações; no caso da personagem Hillé, a problematização entre razão e afeto, sagrado e profano, corpo e casa, as tentativas de designar o que compete ao feminino e masculino. Dicotomias que não são encaradas como forças contrárias a divergirem entre si, mas fundem-se em comunhão no mundo físico experimentado por Hillé.

Embora o dualismo, conforme Gebara (2017), seja componente do imaginário ocidental, a personagem Hillé traz esses elementos considerados opostos e os unem no mesmo corpo, pondo-os em diálogo. O espaço duplicado das personagens possibilita essa interpretação, pois o vão da escada, na narrativa, é onde ficam os personagens vivos e acima da escada aparecem os personagens mortos. 
Observa-se que Ehud aparece na parte superior da escada, e a escada é a expansão de um elemento simbólico para além das superfícies pelas quais o geômetra desejasse defini-la (BACHELARD, 1988), pois demarca a diferença dos mundos espirituais. Quem sobe a escada aproxima-se da elevação espiritual; quem desce a escada se aproxima das angústias, da ansiedade, do medo e mazelas humanas. O que se propõe é a visão de que a personagem Hillé busca o diálogo, sem colocar esses dois mundos como antagonistas.

Assim, a Topoanálise para além do vão da escada, é um espaço de lembranças, do corpo feminino narrativizado pelas experiências que retomam e constroem a trama. Nesse sentido, propõe-se como objetivo específico o não esvaziamento do espaço, para isto, encontra-se embasamento nas reflexões de Michel Foucault (1967). Porque, para ele, todo corpo fala de algum lugar, está em algum lugar, além de estabelecer conexões, construções memoriais; é onde se constrói o simbólico que alimenta identidades.

A obra monumental de Bachelard e as descrições dos fenomenologistas demonstraram-nos que não habitamos um espaço homogéneo e vazio mas, bem pelo contrário, um espaço que está totalmente imerso em quantidades e é ao mesmo tempo fantasmático. (FOUCAULT, 1967, p. 2) 
Para tanto, esta análise faz referência aos seguintes elementos espacializadores: o vivido, o corpo excêntrico envelhecido e a mancha textual da obra. A personagem feminina não se detém às tarefas comumente atribuídas ao feminino. Por outro lado, Hillé vive no excesso das perguntas filosóficas em torno do corpo, da vida pós-morte e da face de Deus. Na tentativa de ter essas respostas, ela recorre à ascese para chegar ao samadhi. No entanto, seu marido falecido Ehud é o antagonista porque interrompe e desvia Hillé da ascese. Nesse desvio, a senhora D passa a buscar Deus no corpo de Ehud, tornando a experiência sexual um encontro carnal sacro.

Toda essa trama é contada em um espaço de desvio da personagem principal que se coloca no vão da escada; desvio do tempo ao fundir passado e presente; desvio da marcação da fala das personagens vivas e mortas; desvio da linguagem ao trazer temas filosóficos em linguagem coloquial e desvio na plasticidade textual, uma vez que se apura o aspecto da fragmentação estrutural na ficção ao mesclar distintos gêneros literários no mesmo texto. Proporcionase a percepção de que a tensão da personagem, de fluxo de consciência e pensamentos truncados plasmam na plasticidade do texto. 


\section{SUBVERSÃO NO ESPAÇO DA LINGUAGEM}

A obscena senhora $D$ ([1982] 2001) é considerada a obra que reúne, de maneira concentrada, todas as temáticas recorrentes nos outros livros de Hilda Hilst. Nesse sentido, as distintas faces de Eros são demonstradas, sendo marcante a figura de erudição e zombaria, filosofia e erotismo dados na mesma importância.

Tem-se, como exemplo, "a morte de Ivan llitch" (HILST, 2001, p. 18), citado em meio ao ato libidinoso entre Ehud e Hillé; a passagem bíblica "ó vinde a mim as criancinhas" (HILST, 2001 , p. 20) colocada em tom de troça; fala-se também em "metafísica da risada" (HILST, 2001, p. 74) aludindo à filosofia bergsoniana; menciona-se a sonata de Mussorgsky (HILST, 2001, p. 62) presente em meio ao descontentamento de uma senhora que mora em uma vila, uma casa colada a outras casas, cujo luxo é demonstrado nas perguntas da personagem na relação entre corpo e espaço.

Além disso, o diferencial da obra está na disposição gráfica do texto, visto que a plasticidade textual é assimétrica, marcando a hibridez de gêneros literários. Em outros livros da autora, principalmente na estrutura dos poemas, houve o predomínio e preocupação com a forma, sendo que a prosa apresenta degeneração estrutural e, também, moral, no que diz respeito às temáticas desenvolvidas. 
Vê-se que, em certos momentos, a prosa se distende em blocos de parágrafos que podem ocupar uma página inteira, expressando um fluxo veloz ao texto. Assim, o modo de expressão estrutural que a escritora construiu no espaço da linguagem desperta atenção. Há um fluxo de palavras que resultam em um grande bloco de parágrafos e, ao mesmo tempo, um ímpeto do instante poético que condensa e potencializa os acontecimentos, de modo que o fluxo é fragmentado e sua estrutura é suprimida na forma de poema.

Dessa maneira, versos são inseridos em meio à prosa, os personagens tomam a posição do narrador. Para Alcir Pécora, os personagens "disputam lugares incertos, instáveis, na cadeia discursiva da narração" (2010, p. 12). Deste modo, eles não operam monólogos, mas dispõem de diálogos sobrepostos que contribuem com o aspecto discursivo da teatralidade.

Vale lembrar que a forma caracterizada pela fragmentação assumida por Hilst não era uma característica estrutural dos seus primeiros livros. Os escritos iniciais são pautados pela lírica, pela figuração de Deus e do amor de forma sublimada. Marcados pela busca de um estado de totalidade idealizada a respeito do divino, do amor, da morte e da sexualidade feminina. Nesse sentido, a potencialização de tais temáticas ocorre conforme a 
escritora vai experimentando outros gêneros e modalidades de escrita; o que se via de sublime é subvertido.

O plano escatológico e risível, confronta e descentraliza a ideia de Deus, passando-o ao plano da personificação e humanização. Veja-se o excerto:

Ai Senhor, tu tens igual a nós o fétido buraco? Escondido atrás, mas quantas vezes pensado, escondido atrás, todo espremido, humilde mas demolidor de vaidades, impossível ao homem se pensar espirro do divino tendo esse luxo, atrás, discurseiras, senado, o colete lustroso dos políticos, o cravo na lapela, o cetim nas mulheres, o olhar envesgado, trejeitos, cabeleiras, mas o buraco ali, pensaste nisso? Ó buraco, estás aí também no teu senhor? Há muito que se louva o todo espremido. Estás destronado quem sabe, Senhor, em favor desse buraco? (HILST, 2001, p. 45)

Os valores morais acerca dessa figura são tão rígidos, social e culturalmente, que não se permite piadas, pois adentra-se à blasfêmia e insulto. Ao romper com a internalização dos valores morais construídos culturalmente, Hillé aproxima o alto ao baixo: Deus e o buraco fétido, em tom zombeteiro. Se, antes, Hilda Hilst tratava de Deus a partir da noção sublimação, na prosa é demonstrado que essa figura centralizadora e eterna é problematizada nas seguintes ocorrências linguísticas: 
[...] Este, O Luminoso, O Vívido, O Nome

[...] Menino Louco [...] Porco-Menino Construtor do Mundo (p. 20) [...] MeninoPorco (p. 25) [...] Menino Precioso, Luzidia Divinóide Cabeça [...] Todopoderoso (p. 37) [...] Como será a cara DELE? [...] é PAI relapso? (p. 38) [...] Senhor, Menino Precioso. (HILST, 2001, p. 46)

Em relação ao amor e à sexualidade feminina, verificase que a subversão se dá quando há a inserção do erotismo como um caminho para o samadhi. Porque é por meio da experiência carnal de si e do eu-outro que a personagem Hillé busca compreender o existir no plano terrestre e para além de sua finitude corporal.

O efeito de subverter a técnica tradicional do gênero prosa é considerado, segundo a crítica literária Eliane Robert Moraes, um "projeto ousado", um "exercício de liberdade" (2017, p. 20) explorador da linguagem no modo literário, guiando intelectualmente os últimos escritos de Hilda Hilst. Em outro momento, Moraes declara que é na prosa hilstiana que "a exploração do desconhecido ganha inusitada violência poética" (1999, p. 118), pois a presença da fragmentação adentra conteúdo e forma.

Isto posto, alguns pontos instigantes da obra aqui analisada merecem atenção. 
A dimensão estética pela assimetria do texto gera a fusão de gêneros e, com isto, o ritmo. Para Pécora, é possível falar em uma prosa "rítmica" ou "poética" (2010, p. 11). O ritmo verbal faz referência ao fluxo e é caracterizado, conforme Massaud Moisés, "pelo tempo, pelo movimento e pela continuidade, que produzem o chamado prazer estético" (1974, p. 447).

Nesse sentido, fazer o uso do ritmo não significa obrigatoriedade o uso da métrica, pois não dependem necessariamente um do outro. Moisés (1974) complementa ainda que, se ambos fossem indissociáveis e funcionassem como determinação, os versos livres não apresentariam modulação.

Novas luzes são lançadas sobre o fazer prosístico. O que é possível verificar na trama de Hillé não é uma cena que se desenvolve enquanto um conjunto de relato dos acontecimentos com fatos e ações, mas um conjunto de estados potencializados pelas imagens poéticas que são expressas dentro de um pensamento estético constituído na linguagem fragmentária. O que de fato acontece? "Sessenta anos. Ela Hillé, revisita, repasseia suas perguntas, seu corpo. O corpo dos outros" (HILDA, 2001, p. 43). Vejase a seguinte passagem:

Desamparo, Abandono, desde sempre a alma em vaziez, buscava nomes, tateava 
cantos, vincos, acariciava dobras, quem sabe se nos frisos, nos fios, nas torçuras, no fundo das calças, nos nós, nos visíveis cotidianos, no ínfimo absurdo, nos mínimos, um dia a luz, o entender de nós todos o destino, um dia vou compreender, Ehud compreender o quê? isso de vida e morte, esses porquês. (HILST, 2001, p. 17-18)

A personagem em seu reduto, onde se experimenta o tempo em simultaneidade. Um espaço que gera a fomentação de questões tortuosas, difíceis de se destrinchar. Por isso, a obsessão pela lucidez e o desejo de redefinir o conceito de morte. A fragmentação prevalece tanto no modo de contar quanto no recurso estético: o espaço da palavra.

Em Brandão, afirma-se que "A palavra é uma manifestação sensível, cuja concretude se demonstra na capacidade de afetar os sentidos humanos, o que justifica que se fale da visualidade, da sonoridade, da dimensão tátil do signo verbal" (2013, p. 64). O fluxo e a fragmentação dos parágrafos conflui com a dificuldade de se fixar uma verdade para as indagações da personagem; a incompreensão de Hillé sobre o próprio corpo e as suas manifestações emocionais do seu mundo interior: "isso de alguém ser muito ao mesmo tempo nada, de olhar o mundo como quem descobre o novo, o nojo, o coagulado, e olhando assim ainda ter o olho adiáfano, impermissível, 
opaco" (HILST, 2001, p. 27); conflui, também, com os diálogos sobrepostos dos demais personagens que não são desenvolvidos em profundidade, são apenas nomes com características esparsas. Veja-se:

he he Luzia, teu traseiro também assusta muita gente teu cu também, tua faccia tua boca repelente sem dente também credo a vizinhança endoidou olha a freira passando olha o doutor com a madama dele olha o cuzaço da madama do doutor. (HILST, 2001 , p. 28 - 29)

Em conivência aos apontamentos de Reuter (2002), os nomes das personagens estão inseridos dentro de uma das "categorias designantes", sendo que o "designante nominal" significa que o personagem tem um nome próprio; já os "designantes perifrásticos" são personagens que têm nomes que não possuem identidade definida; há alguns exemplos de personagens secundárias, como: Luzia, Mãe, MeninoPorco, Antonão, Tunico, "Dia Dez", "Idiotinha”, Pai, Menino.

A concepção de uma totalidade e individualidade sobre o eu é interrompida, o que potencializa a linguagem, a riqueza imagética e, principalmente, o efeito de perturbação com tantas falas sem marcação. Para além de uma manifestação artística resultante de uma expressão sensorial e individual, 
vale lembrar que as modificações socioculturais impactam a estilística.

A exemplo disso, temos o modelo de vida das metrópoles modernas caracterizado por atividades segmentadas e que não é possível compreendê-las em uma totalidade do sistema capitalista. Vale lembrar as palavras de Ernerst Fischer, "a fragmentação do homem e de seu mundo encontra reiterada expressão nas obras de nosso tempo" (1987, p. 107). Assim, os sujeitos modernos e pósmodernos não conseguem apurar a totalidade de onde estão inseridos, pois são alardeados pela fragmentação de distintos pontos de vistas e construções de verdades sobre o mesmo fato.

Os primeiros a enfrentarem essa fragmentação, segundo Fischer, foram os românticos com a questão da desrealização da arte e a decadência do mundo burguês:

Os primeiros poetas da metrópole moderna, Edgar Allan Poe e Baudelaire, adaptaram suas respectivas imaginações criadoras à fragmentária realidade circundante, decompondo na mente o mundo em pedaços para deliberadamente procurar reconstituílo em novo mundo. [...] Escapando a realidade comum, a nova poesia construiu um novo mundo para ela própria. (FISCHER, 1987, p. 108 - 109) 
Relembrando as palavras de Moraes, os modernos trouxeram para a arte a "crise profunda do humanismo ocidental" (2017, p. 53), tendo como fragmentada a figura humana, resultado do caos e tragédias da sociedade.

O uso moderado de elementos formais dá lugar à interação de distintos gêneros textuais, a presença da digressão e o esfacelamento da história e dos personagens. Na citação, Fischer faz referências a alguns poetas modernos, mas não se pode esquecer da subversão da linguagem e das formas tradicionais em Os Cânticos de Maldoror, de Isidore Ducasse (1970).

Vê-se, portanto, a agressão à língua e à sintaxe na forma de expressar a literariedade. Assim como em Hilda, os parágrafos dos Cânticos de Maldoror vão à exaustão da distensão, em um fluxo que passa por cima da forma tradicional. Eis o processo de desmistificação, explicado no seguinte excerto:

Essa destruição das formas tradicionais da linguagem dentro da narrativa [...] equivale ao aspecto molecular de sua atividade contestadora. Essa destruição da 50 linguagem corresponde a uma desmistificação, operada em vários níveis. Desmistificação da retórica, da arte de escrever bem, através da alternância de frases e parágrafos perfeitos, dignos de qualquer "clássico" da literatura, com tôda uma gama de agressões à língua francesa 
e à própria sintaxe; desmistificação do folhetim, da literatura de consumo [...]; [...] desmistificação de todos os bons sentimentos burgueses, e das formas de linguagem utilizadas para expressá-los. (LAUTRÉAMONT, 1970, p. XI - XII)

Nesse sentido, o fazer literário não é apenas um meio para expressar emoções interiores, pois a criação está inserida em um contexto sociocultural e político. O que conflui com a individualidade artística e a forma de expressá-la.

O aspecto da fragmentação ainda não é considerado, em si, um gênero literário, mas uma modalidade de escrita fragmentária cada vez mais recorrente na prosa pósmoderna. É o que esclarece a pesquisadora Maria Luzia Oliveira Andrade:

A fragmentação é uma especificidade dos textos literários, a qual toma forma na sintaxe textual, mediante a não-linearidade discursiva. Também nos remete ao elemento fragmentário, que pode manifestar-se de formas distintas: no esfacelamento de perspectivas, na memória/digressão, no recurso da intertextualidade - prosa/ poesia/drama ou literatura/cinema/teatro - na linguagem sintomática, ou ainda, na coexistência de alguns desses aspectos presentes no mesmo texto. (2007, p. 122)

Na trama de Hillé, tempo e espaço são violados. A efemeridade da personagem é fixada na palavra: "sabe 
às vezes queremos tanto cristalizar na palavra o instante, traduzir com lúcidos parâmetros centelha e nojo, não queremos?" (HILST, 2001, p. 50). O tempo encadeado é rompido, a reunião de instantes vividos forma um mosaico poético em meio à vida comum da vila.

As personagens disputam um lugar de fala, não possuem identidade definida e a sua função no texto contribui com a desordem da sobreposição de vozes, da marcação temporal dos acontecimentos, reiterando o fluxo na trama. Por fim, ressalta-se a temática explorada na composição de uma poética que vai do erudito aos jargões chulos, proporcionando o aspecto cômico e risível.

Diante disso, questiona-se: seria inteiramente livre o estilo que Hilda Hilst criou em sua escrita? Para Alcir Pécora (2010, p. 10), trata-se de uma "anarquia dos gêneros que produz, como se fizesse deles exercícios de estilo" (p. 11), uma "mistura babélica de línguas" (p. 15). Hilst foi leitora dos cânones e buscou construir uma linguagem própria na criação literária, demonstrando que, da ruptura, nasce um estilo que desconstrói o automatismo da percepção de leitura e traz significativas contribuições às concepções teóricas sobre o fazer prosístico. Uma mudança que abala a estrutura narrativa preconizada pela teoria literária. 
Lembrando as palavras do poeta inglês T.S. Eliot, citado por Cícero, "[...] nenhum verso é livre para quem quer fazer um bom trabalho" (2017, p. 97). Acredita-se que há um afastamento da fixidez da velha forma fazendo na medida em que a palavra vai deixando de corresponder somente às práticas utilitárias da linguagem.

A "anarquia de gênero" remete aos apontamentos de Roland Barthes (2013), ao declarar que "a língua não se esgota na mensagem que engendra", pois o signo linguístico deixa de ser realidade sensível e a língua em seu bojo se torna deslocamento, força salutar que reside na literatura; combate ao fascismo.

Por ser um campo em que se criam regras de uso, a língua é o exemplo de que o poder se prolifera para além das instituições sociais, "está presente nos mais finos mecanismos de intercâmbio social" (BARTHES, 2013, p. 13). É pelo fato de o poder se instalar primeiramente na língua que ele tem resistido há tanto tempo.

Em Barthes, o uso da língua pode ser fascista porque "não consiste em impedir de dizer, mas em obrigar a dizer" (2013, p. 15). Há o poder repressivo no modo da fala e escrita. Nesse sentido, A obscena senhora $D$ atua como desvio subversivo, nas regras impostas no uso da língua, ao se contrapor à 
formatação das regras de escrita e estrutura de gênero literário. Assim, a literatura posiciona-se de forma subversiva ou atua com efeito da "desmitificação" (LAUTRÉAMONT, 1970, p. XI).

Pela língua que se oprime e se censura; nesse sentido, o semiologista coloca como necessário o "trapacear a língua", "porque é no interior da língua que a língua deve ser combatida, desviada: não pela mensagem que ela é o instrumento, mas pelo jogo das palavras de que ela é o teatro" (BARTHES, 2013, p. 17). Da língua e linguagem não podemos sair, resta trapaceá-la, traí-la, golpeá-la por meio da literatura, pois, na medida em que ela cria seu cosmos, suas leis desregram normas, o modo de ler a palavra e o mundo, proporcionando novas formas literárias.

É certo que se trata de uma linguagem que fala para todos. No entanto, distingue-se das outras formas de discurso por "violar" e subverter a gramática normativa e o modo utilitário do pensamento cotidiano, em termos barthesianos, uma contracomunicação.

Tais pressupostos provocam a reflexão sobre o espaço que a literatura hilstiana ocupa e em que profundidade tem atingido um incômodo da forma lexical, sintática e temática. A prática literária que busca a autenticidade põe 
em desestabilização não apenas o conteúdo, mas também o modo da estrutura narrativa. Por isso, a escrita de Hilst é antifascista ao subverter a disposição das palavras e suas funções normativas quotidianas.

A forma com que Hilst manipulou a linguagem resultou em uma caracterização estética individual proveniente de leituras anteriores e que expressa marcas de posicionamentos ideológicos e literários. A exploração semântica da autora expressa, conforme Barthes, um "processo de literatura" (2013, p. 17), na medida em que reinventa a linguagem e que trapaceia as normas da língua e o modo de contar. E é aí que se traça um estilo, a ser encarado e assumido. Uma escrita que não é intemporal, não é lançada "à mercê dos ventos", porque, para chegar a essa estética, a escritora precisou pesquisar o que a antecedeu. Foi experimentando os distintos gêneros literários que a sua escrita abarcou a dimensão subversiva, despertando o interesse da crítica especializada.

A disposição da linguagem no modo de contar é um dos pontos em que se constitui a autonomia da literatura. A palavra no texto poético cria imagens que passam a reger a própria realidade, adentrando a "intimidade das substâncias", pois a contemplação já é o próprio aprofundamento nas 
imagens e a ação do espectador sobre as imagens é uma experiência que constitui um universo onírico.

O deslocamento da linguagem, no gênero literário e na estrutura narrativa, resulta na personagem principal Hillé. Há um corpo feminino que questiona a narrativa criada para explicar a origem do mundo e o fim da vida. Um corpo feminino que é anagrama de porco, por se assimilar aos aspectos sagrados e profanos. Um corpo feminino que não é reprimido por ter sessenta anos, mas é provocação à vizinhança por aparecer nu à janela. Um corpo feminino que, através do encontro erótico com o corpo masculino de Ehud, quer também ter acesso ao corpo de Deus.

Tudo isso em um espaço que bifurca a noção do tempo cronológico no momento em que a história acontece. A vivência no vão da escada gera a sobreposição de vozes e a desorganização temporal na trama. As imagens da casa transfiguram as lembranças de Hillé; não se vive a duração concreta da memória, mas, a partir do espaço, as lembranças são localizadas e prevalece o desejo de experienciá-las novamente.

\section{SUBVERSÃO DO CORPO DESLOCADO NO ESPAÇO}

As inovações na prosística contemporânea não eliminam a estrutura clássica; conforme Linda Hutcheon, "a força 
dessas novas expressões sempre provém paradoxalmente daquilo que contestam" (1991, p. 87). Trata-se de uma inserção do híbrido na produção literária porque abarca outros gêneros textuais.

Naturalmente, hoje em dia as categorias de gênero estão sendo desafiadas com frequência (HUTCHEON, 1991, p. 88). A caracterização do gênero literário não pode ser olhada como se fosse estática. $O$ gênero passa por transformações para além da liberdade individual e estilística, porque está em diálogo com a imagem do sujeito em uma época, em uma cultura, em uma sociedade.

As características estilísticas podem ser operadas enquanto uma continuidade ou descontinuidade à forma a que outros escritores estavam adeptos. Para José Lemos Monteiro (2005), querer enquadrar uma obra à intemporalidade é desconsiderar que até mesmo aspectos estilísticos estão atrelados e são constituídos levando em consideração a história da literatura e suas distintas maneiras de produzir linguagem.

Havemos de ver, por exemplo, que a unidade ideológica da burguesia produziu uma escrita única, e que nos tempos burgueses (isto é, clássicos e românticos) a forma não podia ser dilacerada, visto que a consciência também não o estava; e que, pelo contrário, 
a partir do momento em que o escritor deixou de ser uma testemunha do universal para se tornar uma consciência infeliz (por volta de 1850), o seu primeiro gesto foi escolher o compromisso da sua forma, quer assumindo quer recusando a escrita de seu passado. A escrita clássica explodiu então e toda literatura, desde Flaubert até aos nossos dias, tornou-se uma problemática da linguagem. (BARTHES, 2015, p. 8)

Essa consciência infeliz mencionada por Barthes é a forma como Hilda Hilst se relacionou com os assuntos pertinentes à contemporaneidade e de que forma isso foi se transformando em literatura. Embora exista a autonomia da obra, não é mais válido considerá-la, analiticamente, fora de um contexto social. A obscena senhora $D$ participa da sociedade e participa da vida de Hilda Hilst.

A descentralização do sujeito social é marcada pela impossibilidade de homogeneização sociocultural e questionamentos em relação às verdades fixas estabelecidas. Nas palavras de Moraes, "Fragmentar, decompor, dispersar: essas palavras se encontram na base de qualquer definição do "espírito moderno" (2017, p. 53). Nesse sentido, a descentralização é um marco de um "eu" que não exalta, em primeiro plano, a sua vivência interior, mas um eu que vai ao encontro de outro corpo para experienciar a interação da diferença. 
Todas essas modificações na concepção de linguagem literária são advindas da relação com o que Dominique Maingueneau chama de "individualidade criadora e uma sociedade concebida" (1995, p. 45), que consiste em pensar a consciência criadora situada em uma história da literatura.

Essas circunstâncias demandam um posicionamento de Hilst diante do quadro da História da Literatura, um posicionamento no campo literário (MAINGENEAU, 2006). Assim, as condições enunciativas escolhidas por Hilst ao longo do processo de criação constituem uma posição de reinvindicação, uma construção de identidade no campo literário, instaladas na problemática da linguagem, legitimando, dessa maneira, o seu espaço na literatura.

O posicionamento de Hilda Hilst diante das dimensões constitutivas de $A$ obscena senhora $D$ remete a um dos recortes espaciais estipulados por Maingueneau, que é o do campo literário. O que caracteriza essa configuração espacial é o cotejo dos posicionamentos estéticos. É uma exigência ter um posicionamento diante da "diversidade de regimes de produção literária" que partilham de "pressupostos estéticos" (2006, p. 91) para construir sua individualidade.

Na escrita hilstiana algumas temáticas são predominantes e expressam reflexões-questionamentos políticos, escatológicos, 
filosóficos, obscenidades em comunhão ao derrisório. Há também a problematização da circulação da arte inserida em uma sociedade propensa a consumos supérfluos. O posicionamento da escritora no espaço literário confronta as bases do uso da linguagem, da narração e das personagens (principalmente a figura feminina), há a fragmentação da forma estrutural e digressão temática.

Como salienta Hutcheon, trata-se de vir abaixo "a hierarquia da arte elevada e da arte inferior, num ataque à centralização do interesse acadêmico na arte elevada, por um lado, e, por outro lado, à homogeneidade da cultura de consumo" (1991, p. 89). O sujeito pós-moderno revisa a sua posição no mundo, contestando o centro. E a personagem inicia da seguinte maneira "VI-ME AFASTADA DO CENTRO de alguma coisa que não sei dar nome" (HILST, 2001, p. 17). Trata-se de se afastar da centralidade que é Deus e, para ele, a personagem vai atribuindo cognomes.

\section{A PERSONAGEM}

Ao invés de passar o café, servir o marido Ehud e cuidar da vida dos outros como as personagens da vizinhança, a figuração da personagem feminina é tomada por questionamentos filosóficos; além disso, a soberania divina é fortemente contestada de forma risível. Diante disso, a 
personagem é tomada pela angústia de não ter uma resposta exata para todas as suas perguntas.

Vê-se, portanto, a desconstrução do seguinte paradigma: a mulher na velhice e no espaço doméstico. Ao pensar em pessoas idosas, imagina-se o indivíduo repleto de conhecimento e aconselhamento para transmitir, conforme discorre Simone de Beauvoir: "Para outrem, o velho é o objeto de um saber; para si mesmo, ele tem de seu estado uma experiência vivida" (2018, p. 14). É sublimada a imagem sobre o idoso, uma vez que a sociedade considera a velhice como o ápice da sabedoria humana.

Nesse sentido, Beauvoir constitui imagens da velhice levando em consideração a experiência e a impotência. Assim o envelhecimento feminino é carregado de estigmas que relega à imagem da mulher ao diabólico. Na obra analisada, várias passagens remetem a essa perspectiva, pois Hillé é desrespeitada pela vizinhança, seu corpo nu é ridicularizado, dizem que ela tem dois demônios dentro do corpo. A filósofa discorre:

Já que o destino da mulher é ser, aos olhos do homem, um objeto erótico, ao tornarse velha e feia ela perde o lugar que the é destinado na sociedade: torna-se um monstrum que suscita repulsa e até mesmo medo; do mesmo modo que para certos 
primitivos, ao cair fora da condição humana, a mulher assume um caráter sobrenatural: é uma mágica, uma feiticeira com poderes sobrenaturais. (p. 70)

[...] nesses contos, a mulher velha - cuja feminilidade já a torna suspeita - é sempre um ser maléfico. Se alguma vez pratica o bem, é que, na verdade, seu corpo não passa de um disfarce - do qual se despoja, aparecendo como uma fada resplandecente de juventude e de beleza. As verdadeiras velhas são - como nos poetas latinos fêmeas de ogros, feiticeiras malvadas e perigosas. (BEAUVOIR, 2018, p. 142)

Veja-se que a mulher idosa é censurada, seja por levantar dúvidas obsessivas, seja pelas demonstrações consideradas obscenas. Isso é uma decorrência de estereótipos fixados sobre a velhice, um deles é a ideia de que todo idoso é uma fonte de conhecimento consolidado e que sua experiência de vida deve ser difundida para que outros a tomem como um exemplo a ser seguido. Assim, a velhice vem sendo retratada como um processo de conhecimento e desenvolvimento que simplesmente estagnou.

Sábios, filósofos, escritores situam geralmente o apogeu do indivíduo no meio de sua vida. Alguns dentre eles consideram a própria velhice a época privilegiada da existência: ela traz, pensam eles, experiência, sabedoria e paz. A vida humana não conheceria declínio. [...] a velhice não 
poderia ser compreendida senão em sua totalidade; ela não é somente um fato biológico, mas também um fato cultural. (BEAUVOIR, 2018, p. 17)

Por outro lado, se a figura da velhice não está relacionada à sublimação, o sujeito é relegado à condição de louco, caduco "de quem as crianças zombam" (p. 9). Vale lembrar a passagem em que a personagem Hillé está na janela:

o Zico, tô te dizendo, a bruxa quis afagar a cabecinha dele, hoje ela tava sem máscara, com a cara dela mesma, toda amarfanhada, e aquela blusa cor de bosta toda trançada, o mocinho olhou com o zoio assim ó, parou, e cuspiu na mão dela credo, que gente ruim também tu defende a porca?

É caridade, né gente, a mulher tá sozinha, escurecendo ela ficou olhando o cuspe, fechô a mão, fechô a janela bem devagar pro cuspe não cair. São muitas as risadas. (HILST, 2001, p. 73)

A velhice não deixa de ser uma mudança dentro de um corpo e não pode ser considerada como um acontecimento inerte que imobiliza o sujeito ou como se o sujeito fosse considerado inválido. Hillé não é respeitada mesmo estando dentro de sua casa, sua velhice é relacionada à loucura. Mais uma vez a personagem é descentralizada, rejeitada pela vizinhança, ainda que todos estejam de olho no que ela faz ou deixa de fazer: "Hillé, andam estranhando teu jeito de olhar" 
(HILST, 2001, p. 21). E Hillé não se preocupa em agradá-los, "o mundo dos adultos não é mais o seu: recusa as regras e mesmo a moral desse mundo. Não se impõe mais esforço algum" (BEAUVOIR, 2018, p. 14). Esse é um dos aspectos que alimenta a obscenidade.

Nesse sentido, o que Beauvoir traz de relevante é que a velhice corresponde a uma multiplicidade de características impossíveis de defini-la, por isso "não é um fato estático; é o resultado e o prolongamento de um processo" (BEAUVOIR, 2018, p. 14). Ao mesmo tempo em que um corpo idoso é considerado o detentor de saberes, busca-se constantemente ocultar as marcas de deterioração desse corpo e a senhora $D$ toca nesses assuntos sem censura.

Muitas vezes "a velhice aparece como uma espécie de segredo vergonhoso, do qual é indecente falar" (BEAUVOIR, 2018 , p. 7), porque o corpo envelhecido deve ser escondido, não pode ter uma sexualidade, deve ser beatitude. Tratandose da figura feminina, espera-se um comportamento cordial e vestimentas recatadas para ocultar quaisquer traços de sensualidade de um corpo vivido.

Nesse sentido, a personagem é desvalorizada, pois a vizinhança busca limitá-la. Hillé é insubmissa ao deixar de atender aos que buscam encobrir seu corpo e seu 
pensamento filosófico. Por essa insubordinação, a senhora D é rechaçada, mas ainda carrega o lirismo nos olhos e tem muito fôlego para aumentar o "fogo de perguntas". O que a vizinhança da vila deseja é a ficção de um corpo reprimido.

\section{CORPO-CASA-COSMOS}

Segundo Elódia Xavier "Casa é espaço, mas tem um significado muito mais abrangente do que o constituído apenas por um cenário" (2012, p. 9), além disso, "Não um simples cenário da ação narrada, mas uma interseção significativa entre ser e espaço" (2012, p. 15). Assim, foi fundamental pensar o espaço da casa para além de um objeto ou perspectiva geográfica.

Nesse sentido, a personagem Hillé representa mudança no espaço da casa em relação às literaturas que sustentam a figuração sublimada sobre o corpo feminino como a cuidadora do lar. De certo modo, Bachelard traz uma perspectiva utópica em relação ao espaço da casa, porque não leva em consideração os lares que não proporcionam nenhuma segurança habitacional, como é o caso de lares em que há violência, censura, sem proteção ou afeto. Essas questões são mais evidentes nas narrativas de autoria feminina, conforme pesquisa realizada pela Elódia Xavier (2012). 
Em $A$ obscena senhora $D$, a característica fragmentária provoca um espaço descentralizador de Hillé. O centro é foco da contemporaneidade, porque ele passa a ser questionado e subvertido. Esse centro na trama é inatingível porque remete à manifestação do sagrado, um deus cuja presença é universal e que Hillé tanto procura, mas não encontra comunicação em parte alguma, "mas o único meio de compreender um universo mental alheio é situar-se dentro dele, no seu próprio centro, para alcançar, a partir daí, todos os valores que esse universo comanda" (ELIADE, 2010, p. 135).

Nesse sentido, a personagem acredita que existir há de se ter um significado ou ao menos uma dimensão especial. E que ela é parte da criação de uma santidade, ainda que se questione e chame Deus de pai ausente e relapso. Uma divindade é gerada e se arrasta no imaginário de distintas culturas por séculos, também pela necessidade de solucionar o desamparo humano frente à falta de respostas sobre o início e o fim da vida humana. Nas palavras de Nikos Kazantzákis, “Não existe doutrina, não existe Redentor para abrir caminho. Não existe tampouco caminho a ser aberto. Cada qual, elevando-se acima de sua própria cabeça, se evade de seu pequeno cérebro repleto de dúvidas" (1997, p. 148). 
Querer materializar esse Deus é também uma forma de eternizar a humanidade, por isso o esforço de Hillé em dar um rosto ao inominável. Estar à margem desse centro, em um espaço inútil da casa, é estar longe de uma unidade eterna, ao mesmo instante em que se deseja a transmudação do real em algo sobrenatural, para daí extrair respostas das perguntas que, empírica e cientificamente, não foram solucionadas.

Hillé é excesso, em uma situação extrema: ou é lucida ou não é nada, porque não há prudência ou equilíbrio; há obsessão. Muito preocupada com os conceitos de vida, morte, Deus e o corpo. O excesso de Hillé leva "à procura da luz numa cegueira silenciosa, sessenta anos à procura do sentido das coisas" (HILST, 2001, p. 17). Luz, porque trata-se de Deus e cegueira, porque a personagem está morrendo e não sente a vida, mas procura o sentido de viver.

O centro é fragmentado à medida em que é questionado. Não se trata de apurar fatos em uma história linear, mas experimentar estados, deslocar a moralidade ao falar das partes baixas, potencializar o impossível. Veja-se, a seguir, a transcrição de uma anotação de Hilda Hilst sobre a personagem Hillé:

A intensidade da experiência no eu essencial (dependendo da gradação dessa intensidade) afasta o homem da comunidade. Dobrar-se 
sobre si mesmo, "morar no vão da escada", ir até o não mais possível, para emergir. Há alguns riscos nessa Busca, um deles é a loucura, o estar frente a frente com seus demônios e não suportar. Há uma grande esperança: a ressurreição, isto é, uma nova, uma nova e luminosa aceitação de si mesmo, consciente da finitude de sua condição humana, e no entanto o coração e a mente ligados de forma indissolúvel à sua alma imortal. Esta é a estrada do meu tema, a minha obsessão. (HILST apud LEAL, 2018, p. 42)

A personagem descentralizada vê que o centro é um Deus mudo, mas sua existência depende de seus súditos para existir e se manter viva. A posição de Hillé é desafiadora, ela não ouve os conselhos do pai que também viveu um transe, perdeu-se no caminho da busca: "aspirei meus avessos, queria tanto conhecer e agora não só me esqueci do que queria conhecer como também não tenho lembrança do início de todo esquecimento" (HILST, 2001, p. 69). Hillé passa por certas frustrações, porque do sol quis se aproximar do centro, quis o excesso e escureceu: "viver foi uma angústia escura, um nojo negro" (HILST, 2001, p. 52). Por outro lado, a casa deve ser ensolarada para não pesar as ideias sobre o existir.

O centro do sol é escuro e toma conta de tudo caso haja persistência em olhá-lo fixamente: "se persistires o escuro 
toma conta de tudo" (HILST, 2001, p. 72). Essa imagem ressalta que nem todos estão preparados para o que a lucidez reserva, poucos suportam o impacto dessa condição e não sabem o que fazer. Assim, a cultura humana cria distintas narrativas, porque "pensar Deus é apenas uma certa maneira de pensar o mundo" (WEIL apud CARVALHO, 2012, p. 271); nesse sentido, o humano passa a se diferenciar dos outros animais ao atribuir um sentido elevado à existência.

Após ter conhecimento da personagem "ex-cêntrica" (HUTCHEON, 1991, p. 84), em seguida, o discurso fragmentado anuncia o perecimento da personagem no vão da escada. O aspecto do espaço desviante se dá dentro do texto e na plasticidade textual, isto é, desvio do corpo personagem e desvio do corpo do texto. Como se a personagem no vão da escada impactasse também no espaço da linguagem, ou como se a materialidade do texto assumisse a forma descontínua de Hillé, essa que é "polifônica", "porque nela soam várias vozes: a de Ehud, as da vizinhança, a do meninoporco" (LEAL, 2018, p. 61), ou "dialógica" (FOLGUEIRA; DESTRI, 2018, p. 134), por ser atravessada por uma legião de outros discursos no vão da escada, há um ano desde a morte de seu companheiro Ehud. Veja-se, a seguir, o sentido do dialógico analisado por Aline Leal: 
A senhora $D$ apresenta o lançar-se no fluxo da consciência - que, nesse caso, adquire forma dialógica, uma conversa entre Hillé e Ehud - de uma personagem que tende ao transbordamento de sua existência, no limiar de um processo ao mesmo tempo de dessubjetivação e de autoconstrução, que redundará em seu devir-porca. É tornandose porca que Hillé pode tornar-se amante do Porco-Menino, Construtor do Mundo. (2018, p. 60)

Essa ausência de marcação nas interlocuções discursivas entre o companheiro Ehud, o pai e a mãe de Hillé, o PorcoMenino Construtor do Mundo e a vizinhança, faz surgir a memória em sua atualidade. Hillé se concebe como microcosmos, como parte da criação do Todopoderoso. O corpo-carnal é casa e, também, cósmico. O duplo efeito da existência entre pessoas comuns que dividem o espaço terreno e o âmbito para além do terreno das personagens. Nesse sentido, não vivemos em um vácuo, como afirma Foucault (1967) "nada é um vazio", “as imagens habitam" (BACHELARD, 1988, p. 201) o vão da escada e fazem germinar o devaneio do sonhador no espaço da casa.

Deste modo, se a dinâmica da casa e da personagem é uma longitude das formas geométricas, significa dizer que "o espaço transcende o espaço geométrico" (BACHELARD, 1988 , p. 139) porque a ele é atribuído o valor cósmico e o 
ser sonhador alarga os espaços em seu devaneio. À casa é atribuído a tensão e refúgio em que repousa o onirismo da memória e, por isso, está inscrita na personagem, as narrativas constituem a casa e a casa se inscreve em quem a habita, por isso: corpo-casa-cosmos.

Pensar a personagem como o ser da casa não significa remetê-la unicamente à solidão. Repensando essa perspectiva, aponta-se aqui outro viés, o de considerar o mundo da personagem que se abre ao onírico ao dialogar com os mortos e, por meio desse onirismo, Hillé se remodela; por isso essa perspectiva teórica tem "a casa como um instrumento de topoanálise" (BACHELARD, 1988, p. 140). Além disso, a personagem precisava desse exílio como momento de reflexão para chegar ao samadhi.

O pensamento bachelardiano referente à poética do espaço é discutido no plano de uma tentativa de se constituir uma "filosofia da poesia" (BACHELARD, 1988, p. 95) para a análise literária. Essa perspectiva deve reconhecer que o ato poético nunca é vivido da mesma forma, mas sempre renovado. Nessa perspectiva, tem-se a análise dos valores da intimidade interior das imagens do vão da escada e do corpo da personagem. A primeira leitura que se faz de uma casa é a sua rigidez geométrica, mas se levarmos em consideração 
a casa que abriga o ser ou o ser que abriga a casa, esse espaço, topoanaliticamente, se condensa em acolhimento de intimidade que pode se desdobrar ou se suprimir. Por isso a casa "transcende a geometria" para ser espaço dinâmico e não estagnado.

O devaneio germinado pela vivência contrapõe a vida efêmera e desgastante de quem está inserido na sociedade industrial, em que a passagem pelas casas é um estar mecânico, passa-se por ela apenas para descansar muito rapidamente e retornar ao trabalho. Assim, há a desvalorização da vivência e a construção de memórias. Hillé retoma essa vivência, buscando experimentar de todas as formas o mundo físico:

Ardi diante do lá fora, bebi o ar, as cores, as nuances, parei de respirar diante de uns ocres, umas fibras de folha, uns pardos pequeninos, umas plumas que caíam do telhado, branco-cinza, cinza-pedra, cinzametal espelhado, e tendo visto, tenho sido quem fui, sou esta agora? Como foi possível ter sido Hillé, vasta, afundando os dedos na matéria do mundo, e tendo sido, perder essa que era, e ser hoje quem é? Quem a mim nomeia o mundo? Estar aqui no existir da Terra, nascer, decifrarse, aprender a deles adequada linguagem, estar bem não estou bem, Ehud ninguém está bem, estamos todos morrendo. (HILST, 2001, p. 24) 
Nesse sentido, repensando os papéis de gênero comumente retratados na literatura, Hillé surpreende. Seu comportamento é estranho à vizinhança, a imagem da casa do passado fratura a realidade presente, fazendo-se de forma desorganizada e intensa. Para provocar a percepção de fusão do passado e do presente, a ausência de marcação da fala dos personagens, a abolição de pontos finais e a fragmentação da forma imprimem a descentralização e a ideia de estar afastada do centro. O tempo violado gera uma perturbação e revela a procura desnorteada da Hillé, o que justifica sua obsessão pelo conhecimento. Por outro lado, a personagem é muito consciente em relação as partes baixas do corpo que todos buscam esconder.

Uma personagem feminina que não se reduz ao ambiente doméstico "ai ai senhora D não faz assim agora, isso é coisa de mulher desavergonhada" (HILST, 2001, p. 28). Por isso, a casa tem um sentido amplo, porque está em estreita relação com quem a habita. A personagem sobrepõe sua sensibilidade na paisagem da vila onde ela mora. Tem-se uma imagem monocromática cinza que remete a um desgaste, envelhecimento projetado por Hillé. Os sentidos tato, olfato, paladar, audição e visão identificados na primeira linha da citação, são percepções que se fundem, tomam a mesma 
expansão, pois estão em dinâmica e se atravessam numa só impressão (bebi o ar, as cores, as nuances...), ocasionando uma sinestesia no mundo onírico da personagem.

A vivacidade da composição é marcada por elementos táteis, palatáveis e olfativos como arder, beber, respirar, entre outras texturas e sutilezas que se abrandam e projetam uma multiplicidade de afetos que constituem o espaço, através de uma linguagem que nos remete novamente a Bachelard (1988), porque, para ele, atribuir um olhar poético à espacialização do objeto é fazê-lo expandir-se em sua intimidade.

O envelhecimento do corpo aproxima a perspectiva da morte. O corpo da personagem é de palavras, mas as palavras são sensoriais; na medida em que nos relacionamos com as palavras, também nos relacionamos sensorialmente com 0 corpo da personagem. A paisagem não é observada em sua passividade, Hillé acrescenta-Ihes a potencialidade da dimensão do seu estado emocional. Passa-se a pensar na "ambientação dissimulada (ou oblíqua)" desenvolvida por Osman Lins (1976, p. 84), porque a personagem faz surgir os elementos no espaço que a cerca, sendo que Hillé não se demora sobre os aspectos descritivos de sua casa, mas se volta para atitudes como se "o espaço nascesse de seus próprios gestos" (1976, p. 85). 
Veja-se outra imagem poética que endossa essa perspectiva:

Quando Ehud morreu morreram também os peixes do pequeno aquário, então recortei dois peixes pardos de papel, estão comigo aqui no vão da escada, no aquário dentro d'água, não os mesmos, a cada semana recorto novos peixes de papel pardo, não quero mais ver coisa muito viva, peixes lustrosos não, nem gerânios maçãs romãs, nem sumos, suculências, nem laranjas. (p. 19)

Enquanto tu morrias, Ehud, minha carne era tua, e disciplina e ascese tudo que me pretendi para livrar o coração de um fogo vivo. (HILST, 2001, p. 53-54)

A marginalização é do espaço em que Hillé ocupa e, também, do seu corpo tomado pela velhice. Essa recusa das coisas vivas é um estado de ascese para chegar ao samadhi. A ascese é o autocontrole, a disciplina carnal e espiritual, com limitação dos desejos e renúncia aos prazeres, daquele que se prepara para a prática perfeita em determinada atividade, seja física ou intelectual, que começou a ser aplicada à vida moral na medida em que a realização da virtude implica um conjunto de práticas e disciplinas caracterizadas pela austeridade e autocontrole do corpo e do espírito, para se chegar à verdade (CEI, 2016, p. 322). Nietzsche reduz a três as "palavras de pompa do ideal ascético: humildade, pobreza, castidade" (1998, p. 98). 
Outra fonte filosófica para a ascese, também filiada, até certo ponto, ao pensamento nietzscheano, é a perspectiva poética atribuída por Nikos Kazantzákis (1997), um ficcionista da prosa e do verso grego com o qual Hilst encontra significativa interlocução intelectual e artística. Nikos Kazantzákis atribui a Deus nomes como: “Abismo, Mistério, Treva Absoluta, Matéria, Espírito, Última Esperança, Última Desesperança, Silêncio" (1997, p. 34). São nomes refinados se comparados aos nomes que Hilda Hilst escolhe para nomear Deus, pois aproximam aos aspectos baixos do ser humano e, com isso, o aspecto do deboche se faz presente. Sobre o conceito, Paulo Paes (1997) afirma que:

Criada pelos gregos antigos, que com ela designavam todo "exercício", todo treinamento em vista da aquisição de uma mestria. Hoje entendemos por ascese sobretudo um esforço de elevação espiritual, o acesso a um estado superior, a uma consciência purificada das ilusões do mundo. Essa ascese moderna, embora conserve a raiz grega, foi no entanto fortemente influenciada por outra tradição, a judaicocristã, mais propensa a exigir, como requisito para tal elevação, uma renúncia à sensualidade e aos prazeres materiais, tido como o reino da frivolidade e da perdição do homem. (Orelha do livro)

O autocontrole do corpo é uma prática para religiosos mais sistemáticos e funciona como uma automutilação ao 
negar a sexualidade, tanto a biológica, quanto a constituída social e culturalmente. Espera-se que o corpo seja dominado e os desejos sejam reprimidos para alcançar o êxtase espiritual, e a escada é a representação dessa elevação.

O samadhi é um dos níveis mais elevados da meditação no Yoga, sendo o grau máximo da compreensão da existência. Conforme Olga Rodrigues (2020), "samadhi é um estado de total absorção pelo objeto, em que perdemos nossa identidade pessoal. Inclusive, Patanjali diz que nele, aquilo que é compreendido, o objeto de compreensão e aquele que compreende se tornam um".

No entanto, o controle sensorial é tudo o que Hillé não tem, pois viveu a obsessão dessa busca para atravessar o nada que consumirá a vida, os sonhos, o desejo, o amor e toda a potencialidade experimentada pelo sujeito. Hillé quis se afastar da vida ávida, dos sumos e suculências, preferindo peixes pardos que esfarelam no simples toque. Nada muito vívido para não a desviar da busca do samadhi: o compreender da existência. No entanto, essa ascese falha devido à presença de Ehud. Veja-se algumas passagens que fortalecem essa perspectiva:

[...] alma chiii morte chiii, falemos do aqui agora. falando sozinha senhora $D$ ? sabe, Hillé, você deve foder comigo, deve se 
arrumar um pouco" (HILST, 2001, p. 26). "Enquanto tu morrias, Ehud, minha carne era tua, e disciplina e ascese tudo que me pretendi para livrar o coração de um fogo vivo, ah inútil os longos exercícios, a fome do teu toque ainda que me recusasse, então tu não compreendias? queria escapar, Ehud, a boca numa fome eterna da tua boca, a vida era resplendor e prata, demasiada rutilância se tu me tocavas, e sinistra e soluçosa e nada quando tu não estavas. (HILST, 2001, p. 54)

Ehud esteve presente para romper a ascese, pois o caminho para o samadhi pode ser o caminho do afeto, como no movimento filosófico e ritualístico, o tantrismo. A divindade pode estar na partilha da afetividade, do olhar, do toque, nos sentidos do corpo e o sentido que o corpo atribui para si. Outra ruptura da ascese acontece quando Hillé passa a procurar Deus no corpo de Ehud, porque para além da função reprodutiva e luxuriosa, o encontro carnal entre os dois personagens funda o sacroerótico, um ato místico "uma transfiguração da experiência carnal", "a valorização da sexualidade como meio de participar do sagrado" (ELIADE, 2010, p. 140).

[...] fecha os olhos procura imaginar o vazio, o azul seboso, pequenos tombos, eu um homem te tocando porque te amo e porque o corpo foi feito para ser tocado, toca-me também sem essa crispação, é linda a carne, não mete o Outro nisso, não me olhes assim 
o Outro ninguém sabe, Hillé, Ele não te vê, não te ouve, nunca soube de ti, sou eu Ehud, sopro e ternura, sim claro que também avidez e sombra muitas vezes, mas é apenas um homem que te toca, e metemos, é isso senhora $D$, merda, é apenas isso

se muere alguien?

Agora vamos tira a roupa, pega, me beija, abre a boca, mais, não geme assim, não é para mim esse gemido, eu sei, é para esse Porco-Menino que tu gemes, pro invisível, pra luz pro nojo, fornicas com aquele Outro, não fodes comigo, maldita, tu não fodes comigo. (HILST, 2001, p. 63)

Mesmo iluminada pelo erotismo, Hillé ainda busca em profundidade não só a face do sagrado, mas também o contato e a comunhão com o indizível, com algo que nem ela consegue explicar e sacramentaliza o ato sexual, mas não o conclui, uma frustração para o leitor que busca a pornografia nesta obra. Assim, o sagrado não se opõe ou se separa do profano, essa junção é uma experiência valorizada para que o poético aconteça. Georges Bataille lembra que "todo erotismo é sagrado" (1987, p. 15) e que o ser busca insistentemente uma continuidade e essa busca se confunde no erotismo.

Em nossa origem, há passagens do contínuo ao descontínuo ou do descontínuo ao contínuo. Somos seres descontínuos, 
indivíduos que morrem isoladamente numa aventura ininteligível, mas temos a nostalgia da continuidade perdida. Não aceitamos muito bem a ideia que nos relaciona a uma dualidade perdida de acaso, individualidade perecível que somos. (BATAILLE, 1987, p. 15)

A experiência interior endossa o desejo de uma continuidade, uma ligação ao divino além do plano da realidade imediata. O erotismo em Hillé se funde com a busca pela continuidade e fragmenta a noção do ser desligado dos aspectos divinos. Quando a personagem busca o Porco Menino em Ehud, pode significar que se trata da tentativa de se comunicar com o elo perdido, deixando de ser uma experiência sexual individualizada.

Os corpos se abrem para a continuidade através desses canais secretos que nos dão o sentimento da obscenidade. A obscenidade significa a desordem que perturba um estado dos corpos que estão conformes às posses de si, à posse da individualidade durável e afirmada. (BATAILLE, 1987, p. 17)

A intranquilidade da personagem é fomentada pelas questões colocadas pelo seu interior, "seu fogo de perguntas" (HILST, 2001, p. 77). E o acesso ao corpo de Ehud seria a tentativa de se abrir à lucidez. Assim foram as outras experiências da personagem, ao encontrar-se carnalmente com outros corpos. 
A personagem Hillé passa a pensar sobre os afetos nas experimentações corpóreas, porque o que tem relevância não é o ato sexual em si, mas o que nele é possível compreender de si e do outro, como conexão entre o terreno e o divino, um portal para a sacralidade, por isso "Hillé e emoções desmedidas" (HILST, 2001, p. 71). O sagrado e o profano, em irmandade, não eram considerados abomináveis, mas caminhavam juntos.

Isso se torna desgastante para Ehud, que passou a trama inteira pedindo um café nunca feito por sua amada e deseja adentrar o mais fundo de Hillé. Ele diz "também posso foder nesse ridículo vão da escada" (HILST, 2001, p. 23), mas a senhora $D$ está voltada para inquietações metafísicas advindas do próprio corpo e busca Deus no corpo do outro, entender o sentido de ser no mundo: "não venha, Ehud [...] não sei o que é o corpo mãos boca sexo, não sei nada de você Ehud a não ser isso de estar sentado no degrau da escada" (HILST, 2001, p. 23). Estabelece-se uma relação mística sacroerótica através relação de Hillé e Ehud.

As figuras de Ehud e do pai de Hillé suscitam o seguinte questionamento: o que fazer diante da tomada de consciência e compreensão da existência? Estás preparada para o que vai encontrar e o que fazer depois que encontrar 
o que procuras? Para todas as perguntas a posição deles é a seguinte: com Deus ou sem Deus, vive o agora porque o resto sempre será dúvida.

E Ehud diz: "procura compreender, Hillé, agora que estou morrendo" (HILST, 2001, p. 55). O impacto da lucidez é intenso, vale gozar o agora, que passa célere. Não há certezas pós morte, enquanto as narrativas são muitas. Um paraíso, talvez, mas nada determinado, e devido à falta de elucidação, faz-se o paraíso na terra ao lado de quem se está irmanado. Assim, Ehud caminha leve e sabe que o tempo tudo atravessa e desgasta:

Subíamos juntos os degraus desta mesma escada. a cama. o gozo. o ímpeto. depois sono e tranquilidade. e cólera muitas vezes: a vida, morte, teu trânsito daqui pra lá, porra, esquece, segura meu caralho e esquece, te amo, louca. Bonito Ehud. (HILST, 2001, p. 35)

As imagens que se constituem no vão da escada fazem com que a imaginação e as memórias modifiquem a realidade. É um cosmos, um canto no mundo em que ecos ressoam de forma transfigurada por não haver uma ordem nas lembranças nas quais o passado é indefinido. Há o plasmar de uma linguagem entre Hillé e o outro, pois suas ressonâncias interiores se coadunam à fala alheia, uma sobreposição de vozes condensadas no espaço e a partir do 
espaço, tornando-se difícil distinguir quem fala e em que momento se fala. Nesse sentido, tanto o aspecto polifônico, quanto o enredo não linear transformam a narrativa em direções movediças e indeterminadas.

Desperdícios sim, tentar compor o discurso sem saber do seu começo e do seu fim ou o porquê da necessidade de compor o discurso, o porquê de tentar situar-se é como segurar o centro de uma corda sobre o abismo e nem saber como é que se foi parar ali. (HILST, 2001, p. 72)

A fragmentação de um discurso funde o tempo psicológico e o cronológico, o espaço exterior e o interior. Em uma perspectiva bachelardiana, não é o tempo que reaviva a memória, mas a localização do espaço de intimidade do ser sonhador.

É sob o aspecto da fragmentação que a poética de Hillé se constitui: "O tempo da ausência de tempo é sempre presente, sem presença. Esse "sem presente" não devolve, porém, a um passado. Teve outrora a dignidade, a força atuante do agora; dessa força atuante ainda é testemunha a lembrança" (BLANCHOT, 2011a, p. 21).

A personagem que habita o vão da escada sensibiliza os limites geométricos na virtualidade da memória e imaginação. Para Bachelard (1988), não estão dissociadas, há 
mutualidade constituindo uma comunhão. Então o passado não retorna em sua integridade para ser contínuo, o passado retorna transfigurado para ainda ser consumado.

Também nomeada pelo seu amado de: “A senhora D. D de Derrelição" (HILST 2001, p. 17), Hillé parte de fatos emocionais respectivos a seus movimentos interiores, constituindo o espaço de intimidade que começa sendo narrado em primeira pessoa e, posteriormente, o aspecto polifônico se faz presente. Com o falecimento de Ehud, Hillé se recolhe ao vão da escada. O pensar teológico se intensifica, questiona-se a natureza do corpo perseguido pela memória do tempo, do desamparo, "e o que foi a vida? Uma aventura de tão lúcida" (HILST, 2001, p. 71).

Tornam-se perceptíveis experiência interior, um instante poético que emociona e espanta. Fundindo o que aconteceu com os fatos imaginados, tornando a ausência de Ehud, do pai, da mãe e do Construtor do Mundo, uma presença, pois se projeta no exterior a interioridade. Um convite ao leitor a desdobrar o modo sensível em que o texto cria percepções dentro do "espaço aberto" da obra, que constitui o próprio fazer literário.

A memória é também inventiva ao possibilitar nuanças entre o que ocorreu e o que Hillé reconfigurou. Essa 
perspectiva não se iguala ao plano fenomênico enquanto percepção, o qual Bachelard assinala como "perspectiva anulada", esta que tolhe a profundidade do objeto e a possibilidade do onirismo interior, para dar lugar à aparência, à recepção da forma exterior das coisas de forma pacífica. Não se trata apenas de observar o que se tem no espaço, mas nele interferir. Estabelecer diálogos com as ressonâncias interiores de um passado que ainda deseja ser possuído, por isso se faz sempre presente.

\section{CONSIDERAÇÕES FINAIS}

Embora a humanidade, no século $X X$, tenha refinado pesquisas, desenvolvido teorias e criado conceitos para compreender os aspectos que envolve o ser humano, ainda há um insucesso da humanidade em compreender o espaço em que está inserida. Vê-se que essa busca pode permear a loucura ao querer unir o místico ao físico.

Esse quadro da humanidade e da personagem evidencia o malogro do herói. Se no modo épico a figura do herói era usada para servir a um coletivo com colaboração da intervenção dos deuses, o protagonismo do herói na modernidade e pós-modernidade não repercute os mesmos efeitos, já que o autoconhecimento pode desencadear em uma crise. 
Nas reflexões de Ernest Becker (1995), há uma ânsia em criar modelos de heroísmo para tomar como devoção. Contudo, recusa-se a admitir que o heroísmo se torna falível diante de tantas construções de verdade que já não suprem a carência e complexidade em relação à finitude da vida. $\mathrm{O}$ herói não consegue resolver os próprios problemas estando suscetível à crise.

Nesse sentido, loucura e sabedoria são contíguas, sendo difícil determinar onde começa uma e termina a outra, como diz Edgar Morin: "Levar a razão a seus limites máximos conduz ao delírio" (HILST, 2001, p. 27), da mesma forma que “O estado poético nos transporta através da loucura e da sabedoria, e para além delas" (HILST, 2001, p. 9).

A senhora D quer apalpar o sentido das coisas ínfimas, ela vive o que Blanchot nomeia de "gozo doloroso" (2011, p. 196), pois há o sofrimento da ausência de pessoas amadas; em contrapartida, há o desfrute de poder dialogar com eles. Acredita-se que no estado de aguda lucidez sobre a vida, a protagonista não pode se poupar à ausência, pois só nessa circunstância cada coisa encontra o seu lugar, a verdade da personagem só é compreendida na realidade da ficção.

Isso provoca indignação na vizinhança oponente aos seus devaneios; Hillé é chamada de "sapa velha", louca 
e possuidora de demônios: um é Astaroth, que significa vaidade e sedução por meio da beleza, e o outro Asmodeus, que representa virilidade e fertilidade. Diante das possibilidades de leitura, a personagem atinge um estado de lucidez através da logorreia, assim Hillé é obscena, se desloca voluntariamente e se afasta à convenção social.

A ficção traz a representação feminina que toma consciência de si no espaço da casa, em uma outra compreensão de que o feminino também pode fazer parte dos questionamentos e construção do que é a humanidade e transgredindo dogmas que relegaram seu corpo à subalternidade.

\section{REFERÊNCIAS}

ANDRADE, Maria Luzia Oliveira. A fragmentação do texto literário: um artifício da memória? Interdisciplinar. Revista de Estudos em Língua e Literatura, v. 4, 2007.

BACHELARD, Gaston. A poética do espaço. Tradução de Remberto Francisco Kuhnen; Antônio da Costa Leal; Lídia do Valle Santos Leal. São Paulo: Nova Cultural, 1988.

BARTHES, Roland. Aula: aula inaugural de cadeira de semiologia literária do Colégio de França, pronunciada dia 7 de janeiro de 1977. Tradução de Leyla Perrone-Moisés. São Paulo: Cultrix, 2013.

BARTHES, Roland. O grau zero da escrita. Tradução de Maria Margarida Barahona. Lisboa: Edições 70, 2015.

BATAILLE, Georges. O erotismo. Tradução de Antonio Carlos Viana. Porto Alegre: L\&PM, 1987. 
BLANCHOT, Maurice. O espaço literário. Tradução de Álvaro Cabral. Rio de Janeiro: Rocco, 2011.

BRANDÃO, Luis Alberto. Teorias do Espaço Literário. São Paulo:

Perspectiva; Belo Horizonte, MG: FAPEMIG, 2013.

CARVALHO, Cláudio. A mulher no vão da escada: Algumas reflexões sobre A obscena senhora D., de Hilda Hilst. In: CUNHA, Helena Parente et al (Org.). Desafiando o cânone: aspectos da literatura de autoria feminina na prosa e na poesia (anos 70/80). Rio de Janeiro: Edições Templo Brasileiro, 1999.

CEI, Vitor. A voluptuosidade do nada: niilismo e galhofa em Machado de Assis. São Paulo: Annablume, 2016.

CÍCERO, Antonio. A poesia e a crítica: ensaios. São Paulo: Companhia das Letras, 2017.

FOLGUEIRA, Laura; DESTRI, Luisa. Eu e não outra: a vida intensa de Hilda Hilst. São Paulo: Tordesilhas, 2018.

FOUCALT, Michel. De outros espaços. Tradução de Pedro Moura.

Publicado em Diacritics; 16-1, Primavera de 1986.

FISHER, Ernst. A necessidade da arte. Tradução de Leandro Konder. 9. ed. Rio de Janeiro: Guanabara, 1987.

GEBARA, Ivone. Filosofia feminista: uma brevíssima introdução. São Paulo: Edições Terceira Via, 2017.

HILST, Hilda. A obscena senhora D. São Paulo: Globo, 2001.

HUTCHEON, Linda. Poética do pós-modernismo: história, teoria, ficção. Tradução de Ricardo Cruz. Rio de Janeiro: Imago, 1991.

KAZANTZÁKIS, Nikos. Ascese: Salvatores Dei. Tradução de José Paulo Paes. São Paulo: Editora Ática, 1997.

LAUTRÉAMONT, Conde. Os cantos de Maldoror. Tradução de Claudio Willer. São Paulo: Vertente Editora, 1970.

LEAL, Aline. Sob o sol de Hilda Hilst e Georges Bataille. Rio de Janeiro: Azougue Editorial; Editora PUC-Rio, 2018.

LINS, Osman. Lima Barreto e o espaço romanesco. São Paulo: Ática, 1976. 
MAINGUENEAU, Dominique. O contexto da obra literária. Tradução de Marina Appenzeller. São Paulo: Martins Fontes, 1995.

MAINGUENEAU, Dominique. Discurso Literário. Tradução de Adail Sobral. São Paulo: Contexto, 2006.

MOISÉS, Massaud. Dicionário de Termos Literários. São Paulo: Cultrix, 1974. MONTEIRO, José Lemos. A Estilística: manual de análises e criação do estilo literário. Petrópolis: Vozes, 2005.

MORAES, Eliane Robert. Da medida estilhaçada. Cadernos de Literatura Brasileira - Hilda Hilst, São Paulo: Instituto Moreira Salles, n. 8, outubro de 1999.

MORAES, Eliane Robert. O corpo impossível: a decomposição da figura humana: de Lautréamont a Bataille. São Paulo: Iluminuras, 2017. MORIN, Edgar. Amor, poesia, sabedoria. Tradução de Eloá Jacobina. Rio de Janeiro: Bertrand Brasil, 2001.

NIETZSCHE, Friedrich Wilhelm. Genealogia da moral: uma polêmica.

Tradução de Paulo César de Souza. São Paulo: Companhia das Letras, 1998. PÉCORA, Alcir (Org.). Por que ler Hilda Hilst. São Paulo: Globo, 2010.

RODRIGUES, José Carlos. Tabu do Corpo. Rio de Janeiro: Editora FIOCRUZ, 2006.

REUTER, Yves. A análise da narrativa: o texto, a ficção e a narração. Rio de Janeiro: Difel, 2002.

SAFFIOTI, Heleieth. Gênero patriarcado violência. São Paulo: Expressão Popular, 2015.

XAVIER, Elódia. A casa na ficção de autoria feminina. Florianópolis: Mulheres, 2012.

\section{Ana Yanca da Costa Maciel}

Mestre em Estudos Literários-PPG/MEL da UNIR, campus Porto Velho, com bolsa CAPES.

Lattes: https://lattes.cnpq.br/9582913386364951

E-mail: anacmaciel3@gmail.com 